\title{
Geastrum laevisporum: a new earthstar fungus with uncommon smooth spores
}

\author{
Sousa $\mathrm{JO}^{1}$, Baracho GS ${ }^{2}$ and Baseia IG $^{1}$
}

${ }^{1}$ Universidade Federal do Rio Grande do Norte, Departamento de Botânica e Zoologia, Programa de Pós-graduação em Sistemática e Evolução, Campus Universitário, 59072-970, Natal, RN, Brazil.

${ }^{2}$ Universidade de Pernambuco, Instituto de Ciências Biológicas, Laboratório de Biologia Vegetal, Rua Arnóbio Marques, 310, Santo Amaro, CEP 50.100-130, Recife, PE, Brazil.

Sousa JO, Baracho GS, Baseia IG 2015 - Geastrum laevisporum: a new earthstar fungus with uncommon smooth spores. Mycosphere 6(4), 501-507, Doi 10.5943/mycosphere/6/4/12

\begin{abstract}
Geastrum laevisporum is found occurring in the xerophitic shrubland biome named "Caatinga", from Paraíba State, Brazil. Growing in groups on soil, several specimens were collected and studied. The fundamental diagnostic characteristic for this new species is the smooth basidiospore surface. Description, discussion and photographs of this new taxon are given.
\end{abstract}

Key words - Geastraceae - gasteromycetes - taxonomy - biodiversity

\section{Introduction}

Studies of the genus Geastrum Persoon in the semiarid region of Northeastern Brazil have been intensified in recent years. However, the occurrence of species of this genus predominate in Caatinga enclaves of tropical altitudinal moist forests, regionally known as "Brejos de Altitude", and few species occur in more xerophytic plains as well as savanna areas and seasonally dry forests (Leite et al. 2007, Drechsler-Santos et al. 2008, Silva et al. 2011, 2013, Trierveiler-Pereira et al. 2011, Sousa et al. 2014a, b, c).

The Caatinga is an exclusively Brazilian biome, which covers $10 \%$ of the country's area (about $800.000 \mathrm{~km}^{2}$ ). Typical 'Caatinga' vegetation is adapted to water deficiency (low and irregular rainfall), and high temperatures and sun incidences. Trees and shrubs lose their leaves in the driest seasons, decreasing evapotranspiration. The landscape then becomes comprised of naked, whitish wood, which explains the name Caatinga, meaning "white forest" in Tupi, a Brazilian indigenous language (Leal et al. 2005, Prado 2003, Machado et al. 2012).

In general Geastrum species presents basidiospores ornamented with columnar, conical or cylindrical processes (Zamora et al. 2014a). However, species with smooth spores are unusual in this group. The only record of a single species with a sub-smooth basidiospore is Geastrum pleosporum Douanla-Meli described from Cameroon, which presents variable shape of spores (Douanla-Meli et al. 2005). Thus, this work aimed to describe a new species of Geastrum found from the Caatinga biome, Brazil. 


\section{Materials \& Methods}

\section{Collection site}

Paraíba state is situated in the eastern portion of the Northeast region of Brazil, with coordinates between $6^{\circ}$ and $8^{\circ} \mathrm{S}$ and between $34^{\circ}$ and $38^{\circ} \mathrm{W}$, placing it within the tropical zone (Figure 1). It comprises an area of $56,372 \mathrm{~km}^{2}$ and is divided into four mesoregions ('Mata Paraibana', 'Borborema', 'Agreste Paraibano' and 'Sertão Paraibano') and 23 geographic microregions, and includes a total of 223 municipalities (CEPED/UFSC 2011). The samples were collected from an open semiarid area in the extreme western part of the state and in the southcentral portion of the ecoregion of 'Depressão Sertaneja Setentrional', one of the areas most impacted by the anthropogenic actions of the 'Caatinga' biome (Velloso et al. 2002). This area is dominated by the 'Sertão Paraibano' (remote backland), and characterized by its Cretaceous age formation. It is a component of the 'Uiraúna-Brejo das Freiras' region, a smaller intracratonic basin with $480 \mathrm{~km}^{2}$ of great paleontological and geological diversity and relevance. The climate is semihumid (Aw'), warm and dry but with relative humidity of $70 \%$, susceptible to prolonged drought periods, with mean annual precipitation of approximately $770-800 \mathrm{~mm}$. The local flora is characterized by a diversity of many different plant species from the Caatinga to elements of Atlantic Rainforest and Cerrado, including cacti and bromeliads, Solanaceae, Malvaceae, Euphorbiaceae, and many grasses and legumes. The water availability and precipitation seasonality determined by pulses of rainfall separated by intervening dry periods of variable lengths are events that influence and may promote changes in plant performance in arid and semiarid regions (Snyder \& Tartowski 2006).

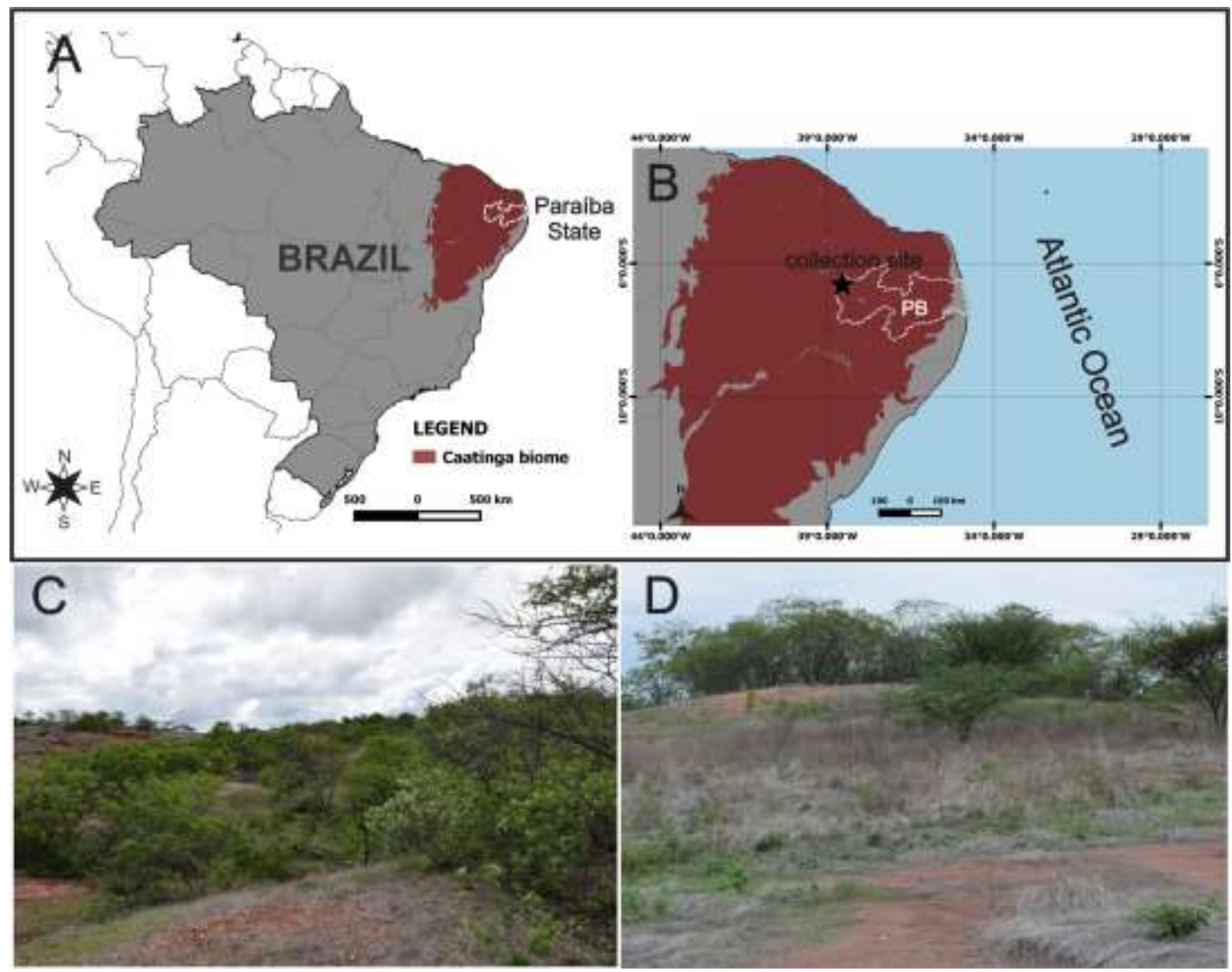

Fig. 1 - Collection Site in 'Caatinga', Brazil. A. Map of the 'Caatinga' biome in Brazil. B. Paraíba State. C-D. landscape images. 


\section{Morphologic study}

Morphological analysis was performed on nineteen dry basidiomata in variable stages of development. All samples were deposited in the Herbarium of the Federal University of Rio Grande do Norte (UFRN-Fungos), Brazil. Macro and micro morphological descriptions were based on specific literature: Bates (2004), Calonge (1998), Sunhede (1989) and Zamora et al. (2014b, 2015). Color terms followed Kornerup \& Wanscher (1978). A Nikon H600L stereomicroscope coupled with a Nikon DS-Ri camera were used for macro morphological study and image capturing. A Nikon Eclipse Ni light microscope coupled with a Nikon DS-Ri camera were used for performing light microscopy (LM). Blades with portions of gleba (basidiospores and eucapillitium) and exoperidial hyphae were all mounted in 5\% KOH (w/v). A Shimadzu SSX-550 was used for scanning electron microscope (SEM) analysis. For this, preparation of the material examined under SEM followed Silva et al. (2011). Basidiospores of the nineteen basidiomata were analyzed; sixteen randomly selected basidiospores were measured using LM at 1000× magnification. Basidiospore abbreviations follow Sousa et al. (2014b): $\mathrm{n}=$ number of randomly measured basidiospores; $x=$ mean \pm standard deviation of basidiospore diameter and height (including ornamentation); $\mathrm{Q}_{\mathrm{m}}=$ mean height/width quotient.

\section{Results}

Geastrum laevisporum J.O. Sousa \& Baseia MYCOBANK: 812507

Fig. 2-4

Etymology - From Lat.: leavi (smooth). Named in reference to the smooth spore surface.

Diagnosis - Expanded basidiomata arched, 7-25 mm wide. Exoperidium mostly arched, strongly hygroscopic. Mycelial layer densely intermixed with sediments, not persistent. Stalk very short, $0.5-0.7 \mathrm{~mm}$ high. Peristome fibrillose, delimited, slightly depressed on endoperidium. Basidiospores yellowish, polymorphous, subglobose, oval to ellipsoid, 6.3-9 (9.9) $\times 5-8.2 \mu \mathrm{m}\left[\mathrm{Q}_{\mathrm{m}}\right.$ $=1.11$ ], thick-walled (up to $0.9 \mu \mathrm{m}$ diam.), smooth to sub-smooth under SEM.

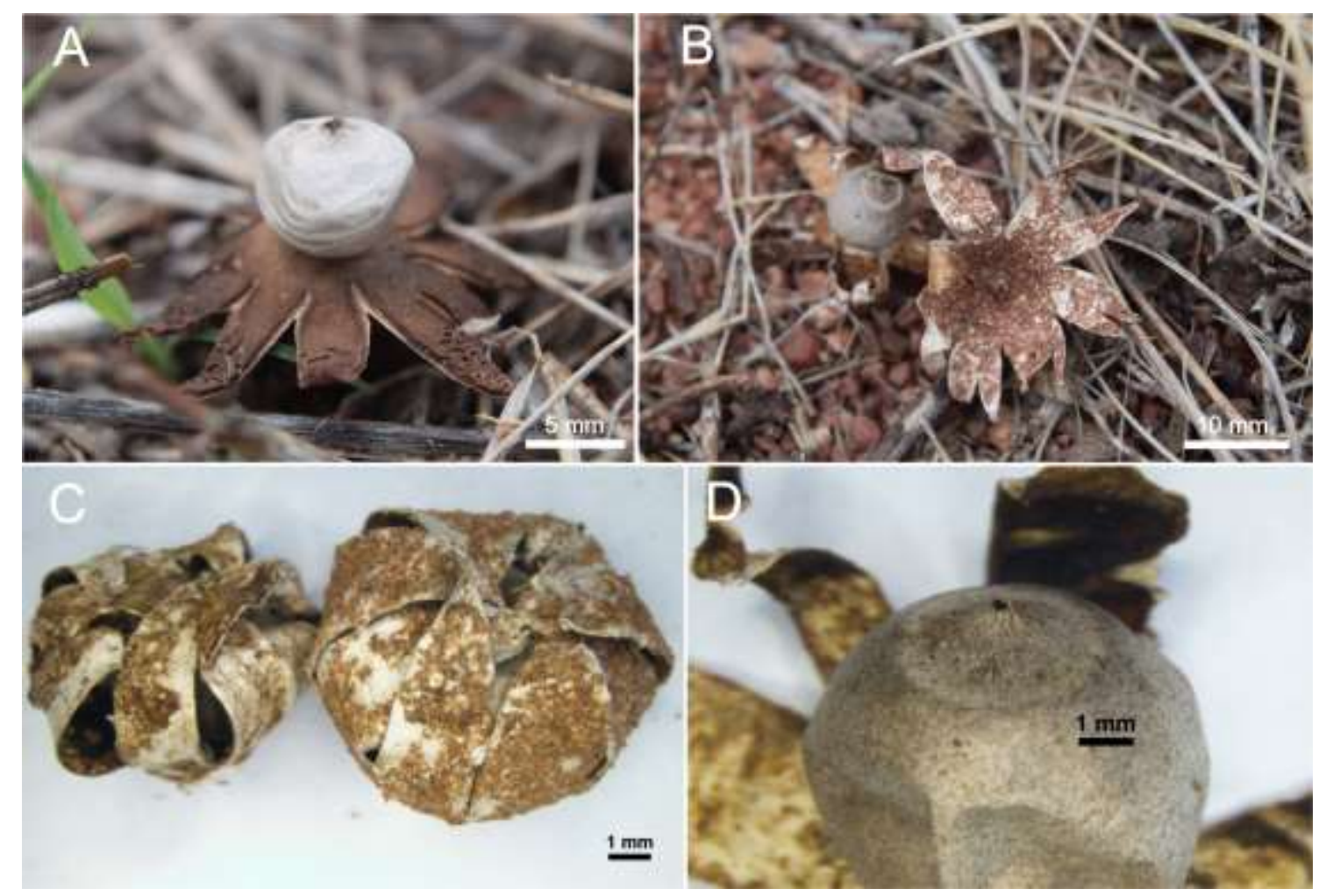

Fig. 2 - Basidiomata in situ (A-B) and ex situ (C-D). A. Basidiomata with arched exoperidium. B. Detailed mycelial layer. C. Basidiomata with strongly hygroscopic rays. D. Detailed peristome. 
Description - Unexpanded basidioma not observed. Expanded basidiomata arched, 5-15 $\mathrm{mm}$ high (including peristome) $\times 7-25 \mathrm{~mm}$ wide. Exoperidium splitting into 8-10 rays, mostly arched, sometimes planar to involute, often completely covering the endoperidial body, strongly hygroscopic. Mycelial layer orange white (5A1), densely intermixed with sediments, felted, peeling away in irregular patches with age exposing the fibrous layer, not persistent. Fibrous layer yellowish white (4A1), coriaceous. Pseudoparenchymatous layer brown (6E5) to dark brown (6F6), rimose on tips of rays, peeling away in irregular patches with age, absent on some basidiomata. Endoperidial body depressed, globose to subglobose, 5-9 × 5-8 mm, stalked, glabrous, nonpruinose, grayish brown (6D2) to grayish orange (6B2). Apophysis absent. Stalk very short, 0.5$0.7 \mathrm{~mm}$ high, lighter than endoperidium. Peristome fibrillose, delimited or weakly delimited, delimitation orange white (5A1), slightly depressed on endoperidium, concolorous with to lighter than the endoperidium, mammiform. Columella not observed. Gleba brown (7E4). Basidiospores yellowish, polymorphous, subglobose, oval to ellipsoid, 6.3-9 (9.9) $\times 5-8.2 \mu \mathrm{m}[x=7.8 \pm 0.7 \times 6.9$ $\left.\pm 0.7, \mathrm{Q}_{\mathrm{m}}=1.11, \mathrm{n}=60\right]$, thick-walled $(0.6-0.9 \mu \mathrm{m}$ diam. $)$, ornamentation inconspicuous under LM; smooth to sub-smooth under SEM. Basidia not observed. Eucapillitium yellowish to hyaline, thin walls $(0.5-1 \mu \mathrm{m}), 3.9-5.9 \mu \mathrm{m}$ diam., sinuous, surface slightly verrucose, encrusted, lumen evident. Mycelial layers composed of hyaline, thin-walled hyphae $(0.4-0.6 \mu \mathrm{m}), 1.8-3.8 \mu \mathrm{m}$ diam., encrusted, lumen evident. Fibrous layer composed of hyaline, thin-walled hyphae $(0.4-1 \mu \mathrm{m}), 4.4-$ $7.4 \mu \mathrm{m}$ diam., sinuous, lumen evident. Pseudoparenchymatous layer composed of thin-walled (0.5$1 \mu \mathrm{m})$ hyphal cells, subglobose to oval, 13.4-32.1 ×11.9-19.3 $\mu \mathrm{m}$. Endoperidium comprised of interlaced hyphae, with an absence of protuberant hyphae.

Habitat - sand soil covered by litter, 'Caatinga' biome (dry forest).

Habit - gregarious.

Specimens examined - BRAZIL - Paraíba State, Triunfo municipality, sítio Jenipapeiro, remnant of Caatinga vegetation, 6 $36^{\prime} 18^{\prime \prime}$ S, 38³2'44" W, 273 m a. s. 1., 28/02/2015, leg. G.S. Baracho 12.179, holotype UFRN Fungos-2587, isotype UFRN Fungos-2588.

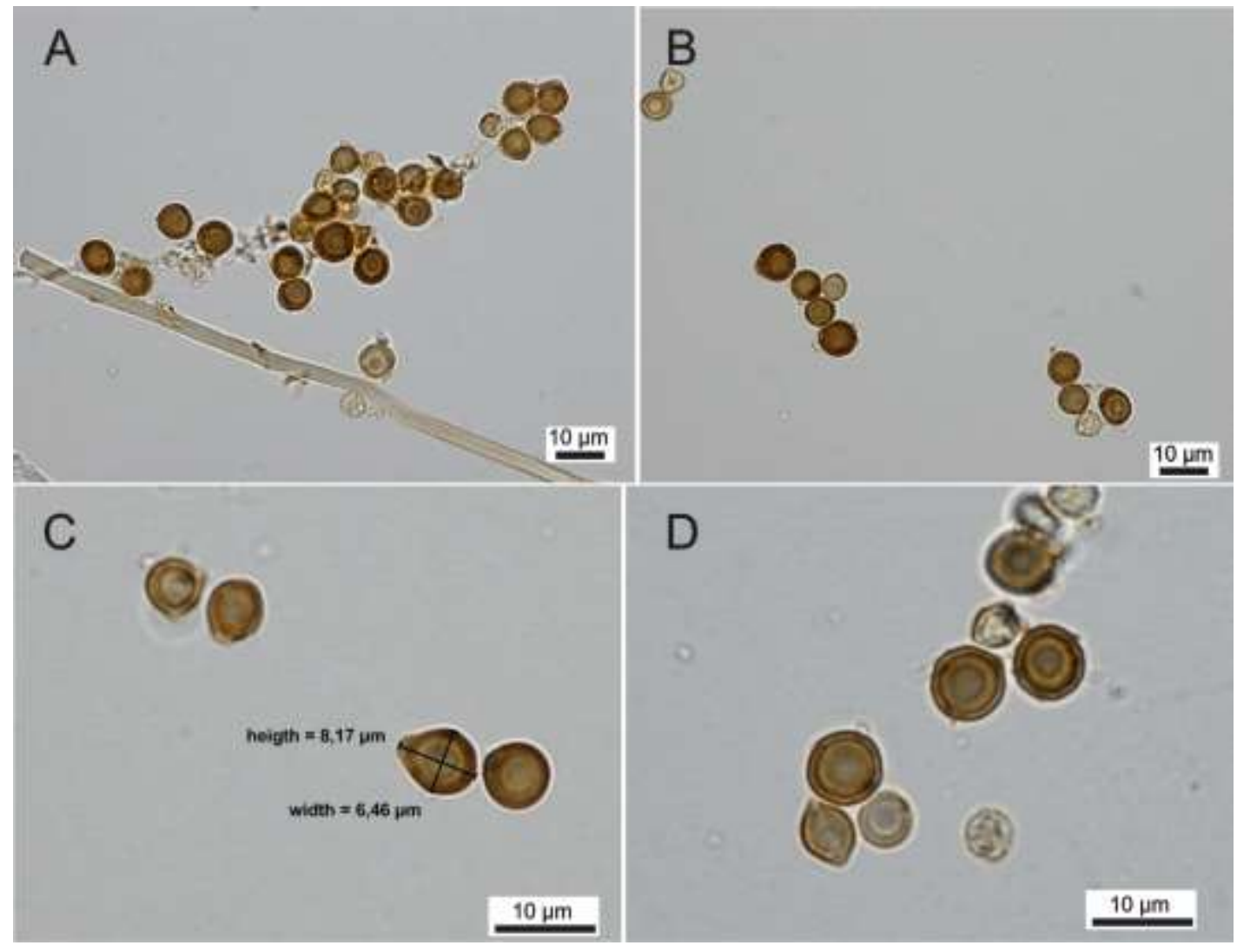

Fig. 3 - Basidiospores under LM (A-D). 


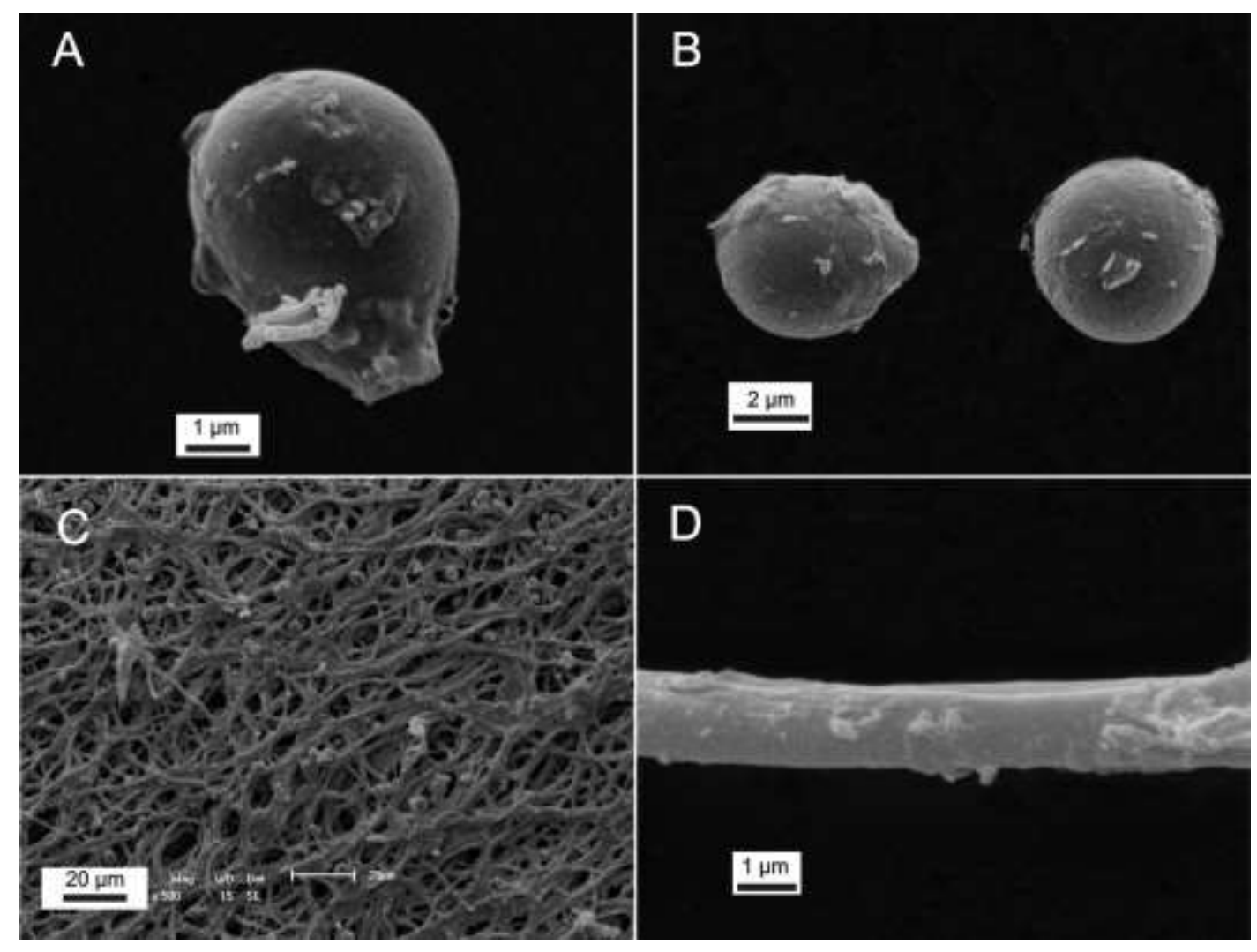

Fig. 4 - SEM images. A-B. Basidiospores. C. Hyphae of endoperidium. D. Eucapillitium.

Remarks - Geastrum laevisporum has a macro morphology typical of the genus Geastrum: star-shaped basidiomata with expoperidium pluristratified splitting in rays, one apical stoma margin by the peristome, and pulverulent mature gleba with true capillitium and basidiospores (Zamora et al. 2014a). This species is mainly characterized by small-sized basidiomata (up to $25 \mathrm{~mm}$ wide); exoperidium densely intermixed with sediments; strongly hygroscopic rays; peristome fibrillose, delimited; and endoperidial body slightly stalked. Geastrum laevisporum is easily differentiated through a microscopic analysis of basidiospores, with size, ornamentation and shape uncommon in the genus Geastrum. The basidiospores are subglobose, oval to ellipsoid $\left(\mathrm{Q}_{\mathrm{m}}=1.11\right)$, have smooth to sub-smooth surface, and height up to $9.9 \mu \mathrm{m}$. These basidiospores patterns were found in the nineteen specimens analyzed in this study.

One species whose basidiospores are a closely related partner is Geastrum pleosporus Douanla-Meli. The basidiospores are also of variable sizes and shapes: globose, cylindrical, elliptic, reniform, and club-shaped basidiospores with (3.5) 4-6 (8) × (3) 4-5 (6) $\mu \mathrm{m}$ Although these are smaller and verruculose under SEM. Moreover, G. pleosporus has a macro morphology completely distinct, differing by saccate basidiomata, delimited peristome, sessile endoperidium, presence of subiculum, exoperidium not encrusted, and non-hygroscopic rays (Douanla-Meli et al., 2005). Another species with oval basidiospores is Geastrum ovalisporum Calonge \& MorenoArroyo, but differs by its distinct delimited peristome; long and small pedicel, up to $2 \mathrm{~mm}$ high; and verrucose basidiospores, up to $3.5 \mu \mathrm{m}$ diam. (Calonge et al. 2000). The largest basidiospores reported before of $G$. laevisporum are found in Geastrum campestre Morgan and G. platense Spegazzini, both with basidiospores just until 8 diam., they differ from G. laevisporum in some macro morphological traits and mainly in shape and ornamentation of basidiospores. Geastrum campestre has plicate peristome, a largest basidiomata (until $40 \mathrm{~mm}$ wide), endoperidium surface covered with warts, and globose, densely verrucose basidiospores. While Geastrum platense has non-delimited peristome, endoperidial body sessile and verrucose basidiospores (Sunhede 1989, Soto \& Wright 2000, Bates 2004). 
Geastrum hungaricum Hollós is a very closely related species in macro morphology. Both G. hungaricum Hollós and G. laevisporum have small-sized basidiomata, exoperidium densely intermixed with sediments, strongly hygroscopic rays, mycelial layer not persistent, fibrous layer whitish, and peristome fibrillose. They are distinguished from each other in that G. hungaricum presents distinctly a delimited peristome and globose, verrucose, smaller basidiospores, up to $6 \mu \mathrm{m}$ (Sunhede 1989). Other species with similar macro morphology are Geastrum corollinum (Batsch) Hollós and G. floriforme Vittad. Both have strongly hygroscopic rays and peristome fibrillose. However, these two species present verrucose basidiospores up to 5 and $7 \mu \mathrm{m}$ in diam., respectively. G. corollinum is distinct in macro morphology, as its peristome is delimited and exoperidium not encrusted; G. floriforme has a sessile, furfuraceous endoperidium (Sunhede 1989, Sousa et al. 2014b).

Until now, there has been no description of any species in the genus Geastrum with the pattern of basidiospores found in Geastrum laevisporum. The morphological evidence and discussion above are sufficient to propose this species as new.

\section{Acknowledgements}

The authors are grateful to the Programa de Pesquisa em Biodiversidade do Semiárido (PPBio Semiárido), Conselho Nacional de Desenvolvimento Científico e Tecnológico (CNPq) and to Universidade de Pernambuco (UPE/PFA, Programa de Fortalecimento Acadêmico) for financial support; and Maria Batista de Freitas (D. Carminha) and family (sítio Jenipapeiro, Triunfo, PB), for the logistical support, kindness, and assistance during fieldwork.

\section{References}

Bates ST. 2004 - Arizona members of the Geastraceae and Lycoperdaceae (Basidiomycota, Fungi). U.S.A: Master Thesis, Arizona State University.

Calonge FD. 1998 - Gasteromycetes: Lycoperdales, Nidulariales, Phallales, Sclerodermatales, Tulostomatales. Flora Micológica Ibérica 3, 271.

Calonge FD, Moreno-Arroyo B, Gómez J. 2000 - Aportación al conocimento de los Gasteromycetes, Basidiomycotina, de Bolivia (América del Sul). Geastrum ovalisporum sp. nov. Boletín de la Sociedad Micologica de Madrid 25, 271-275.

CEPED/UFSC. 2011 - Atlas brasileiro de desastres naturais 1991 a 2010: volume Paraíba. Centro Universitário de Estudos e Pesquisas sobre Desastres, Universidade Federal de Santa Catarina, Florianópolis, CEPED/UFSC, 57 pp.

Douanla-Meli C, Langer E, Calonge FD. 2005 - Geastrum pleosporus sp. nov., a new species of Geastraceae identified by morphological and molecular phylogenetic data. Mycological Progress 4(3), 239-250.

Drechsler-Santos ER, Wartchow F, Baseia IG, Gibertoni TB, Cavalcanti MAQ. 2008 - Revision of Herbarium URM I. Agaricomycetes from the semi-arid region of Brazil. Mycostaxon 104, 918.

Kornerup A, Wansher JE. 1978 - Methuen handbook of colour, 3rd edn., London: Methuen.

Leal IR., da Silva JMC, Tabarelli M, Lacher JR T.E. 2005 - Mudando o curso da conservação da biodiversidade na Caatinga do Nordeste do Brasil. Megadiversidade 1(1), 139-146.

Leite AG, Calonge FD, Baseia IG. 2007 - Additional studies on Geastrum from Northeastern Brazil. Mycotaxon 101, 103-111.

Machado WJ, Prata APN, Mello AA. 2012 - Floristic composition in areas of Caatinga and Brejo de Altitude in Sergipe State, Brazil. CheckList 8(6), 1089-1101.

Prado D. 2003 - As Caatingas da América do Sul. In: Leal, I.; Tabarelli M, Silva, JMC. Ecologia e Conservação da Cattinga. Recife: Ed. Universitária UFPE, 822pp.

Silva BDB, Sousa JO, Baseia IG. 2011 - Discovery of Geastrum xerophilum from the Neotropics. Mycotaxon 118, 355-359.

Silva BDB, Sulzbacher MA, Baseia IG. 2014 - Metodologia. In: Baseia, IG, Silva BDB, Cruz 
RHSF. Fungos Gasteroides no Semiárido do Nordeste Brasileiro. Feira de Santana: Print Mídia, 26-28.

Snyder KA, Tartowski SL. 2006 - Multi-scale temporal variation in water availability: Implications for vegetation dynamics in arid and semi-arid ecosystems. Journal of Arid Environments 65 (2), 219-234.

Soto MK, Wright JE. 2000 -Taxonomia del genero Geastrum (Basidiomycetes, Lycoperdales) em la Provincia de Buenos Aires, Argentina. Boletin de la Sociedad Argentina de Botanica 34 (3-4), 185-201.

Sousa JO, Morais LA, Nascimento YM, Baseia IG. 2014a - Geastraceae. In: Baseia IG, Silva BDB, Cruz RHSF. Fungos Gasteroides no Semiárido do Nordeste Brasileiro. 1ed. Feira de Santana: Print Mídia, p. 37-55.

Sousa JO, Morais LA., Nascimento YM, Baseia I.G. 2014b - Updates on the geographic distribution of three Geastrum species from Brazilian semi-arid region. Mycosphere 3, 467474.

Sousa JO, Silva BDB, Alfredo DS, Baseia IG. 2014c - New records of Geastraceae (Basidiomycota: Phallomycetidae) from Atlantic Rainforest Remmants and Relicts of Northeastern Brazil. Darwiniana Nueva Serie 2(2), 207-221.

Sunhede S. 1989 - Geastraceae (Basidiomycotina). Morphology, ecology and systematics with special emphasis on the North European species. Synopsis Fungorum v.1, 534 pp.

Trierveiler-Pereira L. Calonge FD, Baseia IG. 2011 - New distributional data on Geastrum (Geastraceae, Basidiomycota) from Brazil. Acta Botânica Brasílica 25(3), 577-585.

Velloso AL, Sampaio EVSB, Pareyn FGC. 2002 - Ecorregiões propostas para o bioma Caatinga. Associação Plantas do Nordeste, Instituto de Conservação Ambiental The Nature Conservancy do Brasil, Recife, 76 pp.

Zamora JC, Calonge FD, Hosaka K, Martín MPM 2014a - Systematics of the genus Geastrum (Fungi: Basidiomycota) revisited. Systematics and Phylogeny. Taxon 63(3), 447-497.

Zamora JC, Calonge FD, Martín MPM. 2014b - Systematics of Geastrum sect. Schmidelia and phylogenetic position of G. schmidelii var. parvisporum. Mycologia 106, 1119-1211.

Zamora JC, Calonge FD, MARTÍN MPM. 2015 - Integrative taxonomy reveals an unexpected diversity in Geastrum section Geastrum (Geastrales, Basidiomycota). Persoonia 34, 130-165. 